\title{
Description of a New Species of Pelagic Eelpout Melanostigma thalassium sp. nova (Zoarcidae) from Walvis Ridge (Southeastern Atlantic) and Identification Key for Species of the Genus from the Atlantic Ocean
}

\author{
M. V. Orlovskaya ${ }^{a, *}$ and A. V. Balushkin ${ }^{a}$ \\ ${ }^{a}$ Zoological Institute, Russian Academy of Sciences (ZIN RAS), Saint Petersburg, 199034 Russia \\ *e-mail: Maria.Orlovskaya@zin.ru \\ Received April 3, 2019; revised April 3, 2019; accepted April 4, 2019
}

\begin{abstract}
A new species Melanostigma thalassium sp. n. is described from the underwater Walvis Ridge (Southeast Atlantic Ocean). This species differs from the other species of the genus Melanostigma in an original combination of characters based on the structure of the head's lateral line system (interruption in supratemporal commissure with the loss of medial segments and the absence of pores in the temporal canal) and a nontransparent dark body. In addition, it is different in a range of the count characters in the axial skeleton and fins. A key for identifying the Atlantic species of the genus is provided.
\end{abstract}

Keywords: Melanostigma thalassium sp. n., pelagic eelpouts, taxonomy, Walvis Ridge, Southeast Atlantic DOI: $10.1134 /$ S0032945219050102

\section{INTRODUCTION}

Currently, three species of pelagic eelpouts Melanostigma Günther were known in the Atlantic OceanM. gelatinosum Günther, 1881 (s. str.: south of South America, the Strait of Magellan), M. atlanticum Koefoed, 1952 (North Atlantic), and M. meteori Balushkin et Orlovskaya, 2019 (the Meteor Seamount, Southeast Atlantic). Our previous studies on the species of $\mathrm{Mel}$ anostigma in the Southern Hemisphere (Balushkin, 2019; Balushkin and Orlovskaya, 2019) have shown that some authors consider the species M. gelatinosum as a collecting taxon, consisting of several species within the genus. Therefore, we have decided to refer only the fish in the habitats around southern South America (the Strait of Magellan is a original habitat) to this species. At the underwater Walvis Ridge (Southeast Atlantic), the species of the genus Melanostigma were first found by Trunov (1979), who participated in the marine expedition undertaken by the All-Russia Research Institute of Fishery and Oceanography (AtlantNIRO) on the Salekhard fishery research vessel in 1976. He identified the fish as M. gelatinosum, but he did not indicate the place of capture of the processed specimens in his description. The research paper with original describing the new species $M$. meteori from the Southeast Atlantic (Balushkin and Orlovskaya, 2019) suggested that the specimens of pelagic eelpouts analyzed by Trunov could be referred to the species M. meteori rather than to M. gelatinosum.
This was indicated by the varying numbers of dorsal and anal fin rays, which were rather similar to those in $M$. meteori (the other characters important in the recent diognostics of species within the genus Melanostigma were absent in the description). The problem with species identification of specimens within the genus Melanostigma at the Walvis Ridge appeared to be solved after finding several specimen samples of genus Melanostigma in the ZIN RAS non-catalyzed collections, which were captured during the expedition in 1976. Unfortunately, they could not be found before the preparation of the ZIN RAS collection catalogs, dedicated to the eelpout fish (Balushkin et al., 2011; Balushkin et al., 2012). The analysis of these fish has proven that they are identified as the new species $M$. thalassium $\mathrm{sp}$. $\mathrm{n}$. The article deals with the description of this new species.

\section{MATERIALS AND METHODS}

In order to perform the comparative analysis, the ZIN RAS collections of $M$. atlanticum, M. pammelas, and $M$. gelatinosum were used. M. atlanticum: no. 48529-one specimen, Atlantic Ocean, near the Cape Verde Islands, $22^{\circ} 30^{\prime} \mathrm{N} 17^{\circ} 22^{\prime} \mathrm{W}, 1000-1200 \mathrm{~m}$ depth, R/V Zvezda Kryma, trawl 173, January 20, 1973, collector G.A. Golovan; no. 44898-eight specimens, Atlantic Ocean, Norfolk Canyon, Virginia, United States, $37^{\circ} 26^{\prime}$ N $74^{\circ} 20^{\prime} \mathrm{W}, 630-750 \mathrm{~m}$ depth, R/V Estward, station 46, July 3, 1975, collector 


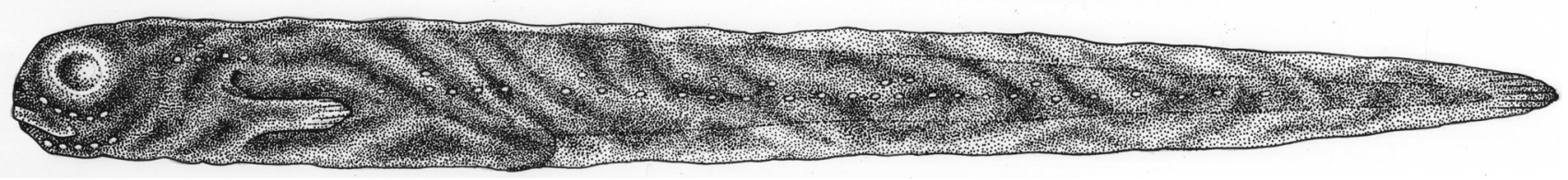

Fig. 1. Holotype Melanostigma thalassium Orlovskaya et Balushkin sp. n., ZIN no. 56395-TL $123 \mathrm{~mm}, S L 117 \mathrm{~mm}$, R/V Salekhard, Southeastern Atlantic, Walvis Ridge, 3316'2" S, 02 ${ }^{\circ} 17^{\prime} 4^{\prime \prime}$ E, 960-1080 m depth.

J.A. Musick; no. 56415-one specimen, Atlantic Ocean, Denmark Strait, $65^{\circ} 13^{\prime}$ N $33^{\circ} 24^{\prime} \mathrm{W}, 843 \mathrm{~m}$ depth, R/V Paamint, trawl 20, June 27, 2006, collector P.R. Møller. M. pammelas no. 25871-one specimen, Pacific Ocean, Monterey Bay, California, United States, $36^{\circ} 40^{\prime} \mathrm{N} 122^{\circ} 07^{\prime} \mathrm{W}$, July 6, 1931, collectors T. Skogsberg and R.L. Bolin. M. gelatinosum no. 48064-one specimen, Pacific Ocean, near the coast of Chile, $42^{\circ} 24^{\prime} \mathrm{S} 74^{\circ} 45^{\prime} \mathrm{W}, 470-440 \mathrm{~m}$ depth, R/V Akademik Knipovich, voyage 12, trawl 128, February 26, 1973, collectors V.N. Efremenko and V.P. Prirodina.

In addition, the exploratory comparative study included the following type specimens: $M$. inexpectatum Parin (ZIN no. 42640, holotype), M. japonicum Balushkin (Museum, Biological Sciences Department, Kochi University, Japan (BSKU), BSKU no. 44840, holotype); M. kharini Balushkin et Moganova (ZIN no. 56163-56164, three specimens, type series); M. meteori Balushkin et Moganova (ZIN nos. 56303, 45933, and 45934, five specimens, type series), M. olgae Balushkin et Moganova (ZIN nos. 56159 and 45931, seven specimens, type series), $M$. orientale Tominaga (Department of Zoology, University Museum, University in Tokyo, Japan (ZUMT), ZUMT no. 52454, X-ray image of the holotype), and M. vitiazi Parin (ZIN no. 44000, holotype). More data contained in the labels for these fish were previously described (Tominaga 1971; Parin, 1977; Balushkin and Moganova, 2017, 2018; Balushkin, 2019; Balushkin and Orlovskaya, 2019).

The description of a new species followed the model scheme applied in our previous publications (Balushkin and Moganova, 2017, 2018; Balushkin and Orlovskaya, 2019). Both the numbers of rays in the dorsal, anal, and caudal fins and the numbers of vertebrae were calculated with the use of the digital image data on the roentgenograms produced with the PRDU-02 X-ray system. The measurements of vertebrae were performed with the use of four abdominal vertebrae (from the fifth to eighth vertebrae). Gill rakers and the rays in the pectoral fin on the right side of the body were calculated. The first author makes the drawings. The description provides the first figure for a holotype, while the figures in brackets refer to the paratypes.

\section{RESULTS AND DISCUSSION}

Melanostigma thalassium Orlovskaya et Balushkin sp. n.-Talassian pelagic eelpout

(Fig. 1)

Melanostigma gelatinosum (non Günther, 1881): Trunov, 1979, p. 135 (body color and count characters: $D$ 83-89, $A$ 74-75, $P$ 8); Trunov, 1981, p. 53 (in the list).

Holotype. ZIN no. 56395-TL $123 \mathrm{~mm}, S L$ $117 \mathrm{~mm}, \mathrm{R} / \mathrm{V}$ Salekhard, Southeast Atlantic, Walvis Ridge, $33^{\circ} 16^{\prime} 2^{\prime \prime}$ S $02^{\circ} 17^{\prime} 4^{\prime \prime}$ E, 960-1080 m depth, August 31, 1976, collector I.A. Trunov.

P a ratypes. ZIN no. 56396-four specimens, $T L 116,103$, 99, and $93 \mathrm{~mm}, S L 110,99,92$, and $89 \mathrm{~mm}$, caught along with a holotype. ZIN no. 56396a-one specimen. TL $109 \mathrm{~mm}, S L 104 \mathrm{~mm}$, alizarin specimen preparation, separately preserved in glycerin.

D i a g n os is. Supratemporal commissure interrupted in middle between lateral segments (senses). Medial sense absent. No pore in temporal canal. Body lateral line with three series of neuromasts (predorsal, dorsolateral, and mediolateral). In the first branchial arch, 27-30 gill rakers, including 13-14 gill rakers in external row and $14-17$ gill rakers in internal row. Pectoral fin with $8-10$ rays. Vertebrae number $90-92$, including 20-21 abdominal and 70-71 caudal vertebrae. Vertebrae elongated and slightly asymmetrical. Length for anterior part of center of body vertebrae (in the region of fifth to eighth vertebrae) comprises 73$88 \%$ of length of its posterior part. Maxilla length 3.9$5.4 \% S L$. Upper lip tends to coalesce with snout. Whole body monotonous dark and nontransparent.

Main meristic characters (Table 1). $D 85$ (84-86), $A 70$ (70-72), and $P 9$ (8-10); vert. $20+$ $70=90(20-21+70-72=90-92), C 10(10)$; gill rakers on first branchial arch in external row $0+14=14$ $(0-1+13-14=13-14)$; gill rakers in internal row $1+$ $15=16(0-1+13-16=14-17)$, up to three rows of small conical teeth at symphysis of jaws.

Body low, significantly elongate, and thinned towards end. Maximum height in anterior part of trunk, comprising $8.5 \%$ (7.7-8.7\%) SL. Caudal fin narrow and rounded at end. Skin tender, semitransparent, and movable with developed jelly-like layer and without scales. Head small, containing 7.9 (7.38.6) times in $T L$, snout elevation very steep. Mouth terminal, clift of mouth slightly oblique, reaching ver- 
Table 1. Morphometric characters of Melanostigma thalassium sp. n. type series (collection of ZIN RAS)

\begin{tabular}{|c|c|c|c|c|c|c|}
\hline \multirow[b]{2}{*}{ Character } & \multirow{2}{*}{$\begin{array}{c}\text { Holotype } \\
\text { ZIN no. } 56395\end{array}$} & \multicolumn{5}{|c|}{ Paratypes } \\
\hline & & $\begin{array}{c}\text { ZIN no. } 56396 \\
\text { (1) }\end{array}$ & $\begin{array}{c}\text { ZIN no. } 56396 a \\
\text { (2) }\end{array}$ & $\begin{array}{c}\text { ZIN no. } 56396 \\
\text { (3) }\end{array}$ & $\begin{array}{c}\text { ZIN no. } 56396 \\
\text { (4) }\end{array}$ & $\begin{array}{c}\text { ZIN no. } 56396 \\
\text { (5) }\end{array}$ \\
\hline$T L, \mathrm{~mm}$ & 123.7 & 116.3 & 109.2 & 103.6 & 99.6 & 93.4 \\
\hline$S L, \mathrm{~mm}$ & 117.3 & 110.5 & 104.3 & 99.2 & 92.5 & 89.5 \\
\hline$h$ & \multicolumn{6}{|c|}{$\% S L$} \\
\hline$a A$ & 34.7 & 33.7 & 33.6 & 36.0 & 33.0 & 32.5 \\
\hline$p A$ & 69.9 & 70.9 & 72.4 & 69.0 & 75.2 & 69.1 \\
\hline$I B r A$ & 21.1 & 23.8 & 17.3 & 19.8 & 18.8 & 21.6 \\
\hline$l P$ & 8.3 & 6.9 & 7.4 & 9.4 & 9.4 & 6.3 \\
\hline$B r P$ & 1.5 & 1.1 & 1.6 & 2.0 & 1.5 & 0.9 \\
\hline$d B r$ & 1.5 & 1.1 & 1.3 & 1.2 & 1.0 & 1.1 \\
\hline$H$ & 9.2 & 9.6 & 9.6 & 8.7 & 8.4 & 7.9 \\
\hline$c$ & 13.3 & 12.3 & 13.4 & 14.3 & 13.9 & 14.1 \\
\hline$w c$ & 7.0 & 6.1 & 7.3 & 6.9 & 6.8 & 6.5 \\
\hline ch & 8.4 & 8.5 & 8.7 & 9.0 & 8.4 & 7.8 \\
\hline $\operatorname{lm} x$ & 4.8 & 5.2 & 5.4 & 5.1 & 4.9 & 3.9 \\
\hline$a o$ & 3.0 & 3.3 & 3.7 & 4.3 & 2.5 & 3.0 \\
\hline io & 4.9 & 5.1 & 5.7 & 5.5 & 4.6 & 5.1 \\
\hline \multirow[t]{2}{*}{$o$} & 4.0 & 4.4 & 4.5 & 4.5 & 4.3 & 5.6 \\
\hline & \multicolumn{6}{|c|}{ Meristic characters } \\
\hline$D$ & 85 & 86 & 86 & 84 & 86 & 85 \\
\hline$A$ & 70 & 71 & 71 & 70 & 72 & 72 \\
\hline$P$ & 9 & 8 & 10 & 10 & 8 & 8 \\
\hline$C$ & $2+4+4=10$ & $2+4+4=10$ & $2+4+4=10$ & $2+4+4=10$ & $2+4+4=10$ & $2+4+4=10$ \\
\hline sp. br. ant. & $0+14=14$ & $0+13=13$ & $1+13=14$ & $1+13=14$ & $0+13=13$ & $0+14=14$ \\
\hline sp. br. post. & $1+15=16$ & $1+16=17$ & $0+16=16$ & $0+16=16$ & $1+13=14$ & $1+15=16$ \\
\hline $\mathrm{CIO}$ & $5 / 5$ & $5 / 5$ & $5 / 5$ & $5 / 5$ & $5 / 5$ & $5 / 5$ \\
\hline$C P M$ & $5 / 5$ & $5 / 5$ & $5 / 4$ & $5 / 5$ & $5 / 5$ & $5 / 5$ \\
\hline CSO & $1 / 1$ & $1 / 1$ & $1 / 1$ & $1 / 1$ & $1 / 1$ & $1 / 1$ \\
\hline$C T$ & 0 & 0 & 0 & 0 & 0 & 0 \\
\hline$C S T$ & 0 & 0 & 0 & 0 & 0 & 0 \\
\hline \multirow[t]{2}{*}{ vert. } & $20+70=90$ & $21+71=92$ & $20+72=92$ & $21+69=90$ & $21+71=92$ & $19+71=90$ \\
\hline & \multicolumn{6}{|c|}{ Indices } \\
\hline$T L / c$ & 7.9 & 8.6 & 7.8 & 7.3 & 7.7 & 7.4 \\
\hline$T L / c h$ & 12.5 & 12.4 & 12.0 & 11.6 & 12.8 & 13.3 \\
\hline$T L / h$ & 12.4 & 12.1 & 12.0 & 13.5 & 13.1 & 13.5 \\
\hline$T L / a A$ & 3.0 & 3.1 & 3.1 & 2.9 & 3.3 & 3.2 \\
\hline$T L / I P$ & 12.8 & 15.3 & 14.2 & 11.1 & 11.4 & 16.7 \\
\hline$T L / I B r A$ & 5.0 & 4.4 & 6.1 & 5.3 & 5.7 & 4.8 \\
\hline$c / l P$ & 1.6 & 1.8 & 1.8 & 1.5 & 1.5 & 2.3 \\
\hline$c / o$ & 3.3 & 2.8 & 3.0 & 3.2 & 3.2 & 2.5 \\
\hline$I B r A / c$ & 1.6 & 1.9 & 1.3 & 1.4 & 1.3 & 1.5 \\
\hline
\end{tabular}

$T L$ - total length; $S L$-standard length; $h$-body depth at the beginning of the anal fin (including a membrane of $D$ ); $a A$-anteanal distance; $p A$-postanal distance (up to end of rays $C$ ); $l B r A$-distance from the posterior edge of the gill slit to middle of anus; $l P-$ length of pectoral fin; $B r P$-distance from lower edge of gill slit to base of first ray of pectoral fin; $d B r$-horizontal diameter of gill slit; $H$-maximum body depth; $c, w c$-head length and width; $c h$-head depth through the orbit center; Imx-length of upper jaw; ao-snout length; $i o$-width of the interorbital distance; $o$-orbit horizontal diameter; $D, A, P$-numbers of rays in dorsal, anal, and pectoral fins; $C$ number of caudal fin rays (epurale rays + rays on both hypural plates); $s p$. $b r$. ant.-number of gill rakers in external row of first branchial arch; sp. br. post. - number of gill rakers in internal row of first branchial arch; CIO, CPM, CSO, CT, CST-seismosensory pore numbers in infraorbital, praeoperculo -mandibular, supraorbital, temporal canals, and supratemporal commissure, respectively; vert. - number of vertebrae (abdominal + caudal). 


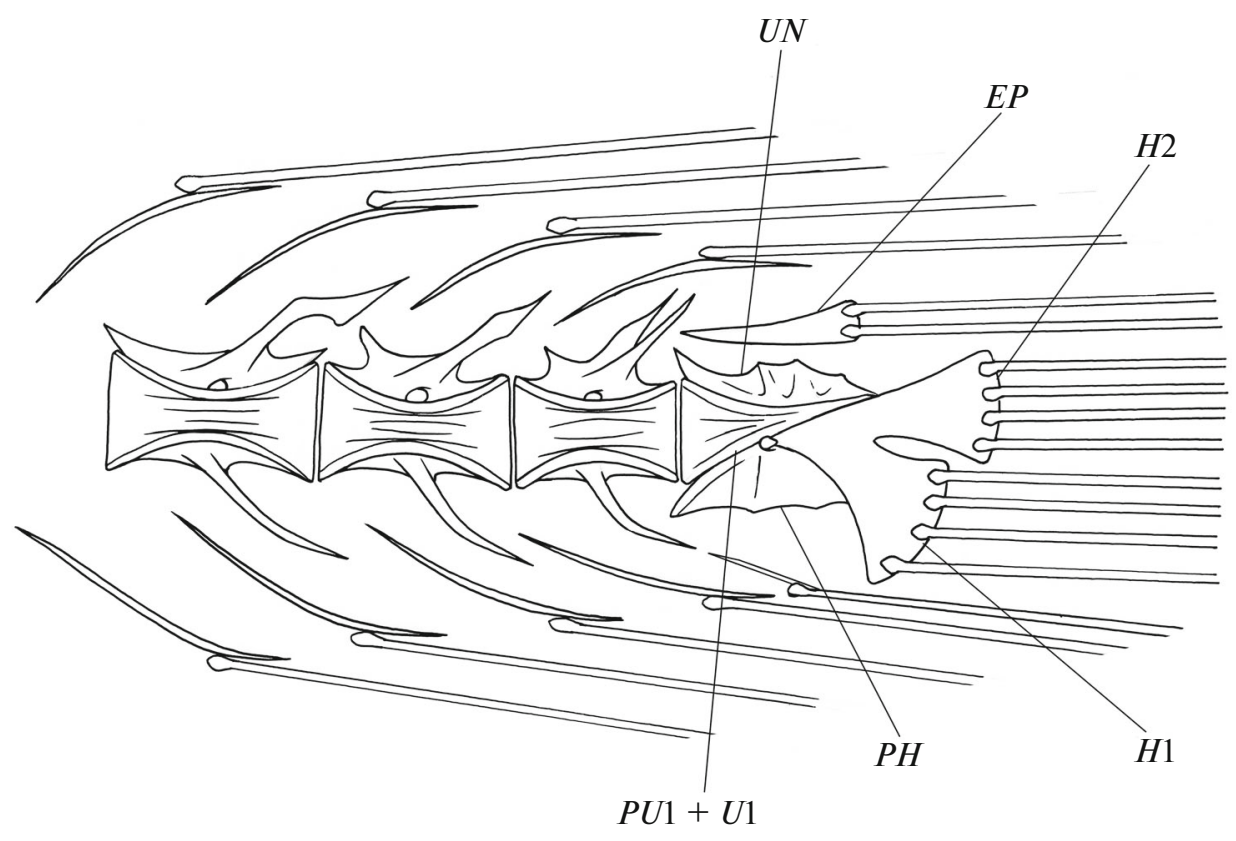

Fig. 2. Caudal fin skeleton in Melanostigma thalassium (holotype, ZIN no. 56395-TL $123 \mathrm{~mm}, S L 117 \mathrm{~mm}$ ): $U N-$ uroneurale; $E P$-epurale; $H 1$-hypaxial hypural; $H 2$-epaxial hypural; $P H$-parhypural; $P U 1+U 1$-urostylar vertebra $(P U 1-$ preurale 1 , $U 1$-urale 1).

tical through anterior edge of orbit. Pair of nostrils with low tubes dark brown in color. Gill opening small, situated beyond upper edge of pectoral fin at distance equal to its vertical diameter. Six branchiostegal rays. Gill rakers simple without bifurcated ends.

Teeth of jaws conical and movable, diminishing in size backwards, extending as two to three rows on premaxilla close to symphysis of maxillae and as one row locating further back. Teeth on vomer (five teeth in holotype) and on palatine bones.

Ro entge nogram. Two vertebrae up to first pterygiophore $D 4$ (3-4), before first caudal vertebra (1-3) of pterygiophore, supporting first rays of anal fin. Vertebrae amphicoelous with strong neural arches provided with large zygapophyses. Prezygapophyses of vertebra overlie postzygapophyses of preceding vertebra. Parapophyses usually visible from third (third to fourth) vertebra. Epipleuralia extend from third (third to fourth) vertebra to no longer than ninth (sixth to ninth) vertebra. Pleuralia extend from the third (third to fourth) vertebra to no longer than eighth (sixth to seventh) vertebra.

Two hypural (epaxial and hypaxial) plates fused in holotype with urostylar vertebra $(P U 1+U 1)$. Epaxial plate connected with center only in distal part (Fig. 2). Parhypurale weakly developed, not involved in supporting $C$ rays. One epurale, weakly ossified, bone elongated, hanging in front of posterior part of preurostylar vertebra (preurale 2), behind it supports $2(1-2)$ upper rays of $C$. No upper spinous process (spine) on preurostylar vertebra. In paratypes, variations generally observed in both construction of preurostylar ver- tebra, which happens to contain one to three vertebrae, and forms of epaxial and hypaxial plates, which do not generate even posterior edges in order to attach principal rays of fin. Numbers of principal rays $C$ in all paratypes equal eight (four rays on epaxial plate + four rays on hypaxial plate).

S e is mosensory syste m of head composed of both paired supraorbital (CSO), infraorbital (CIO), temporal $(C T)$, and preopercular-mandibular $(C P M)$ canals and unpaired supratemporal commissure $(C S T)$. First three canals joined to each other behind the eye. Preopercular-mandibular canals isolated, since they do not have any connections between one other and temporal canals. Supraorbital canals without connection between one other (coronary commissure absent). Supratemporal commissure interrupted in middle with loss of medial segments. Five (four to five) pores on each side of $C P M$ and $C I O$. Pores of both canals relatively large (first pores of these canals, pio 1 and ppm 1, smaller than other pores). CT and CST without pores. In $C S O$, one visible pore, located anterior and more medial than nostril.

Structural elements of the canals analyzed in paratype no. 56396 (first and second specimens) (Fig. 3) represented by $C S O$ four senses ( $S O I$ (=nasale), SOII, $S O I I$, and $S O I V)$ and $C I O$ eight senses, including three senses in lacrimale (IOI-IOIII) and five senses corresponding to infraorbital bones (infraorbitale 2infraorbitale 6). $C T$ with two senses: $C T I$ in pteroticum and $C T I I$ (tabulare temporale). $C S T$ runs from location of fusion of these canals. Four senses in $C P M(P M$ I- $P M$ IV), located on mandible. $C S T$ with one sense 


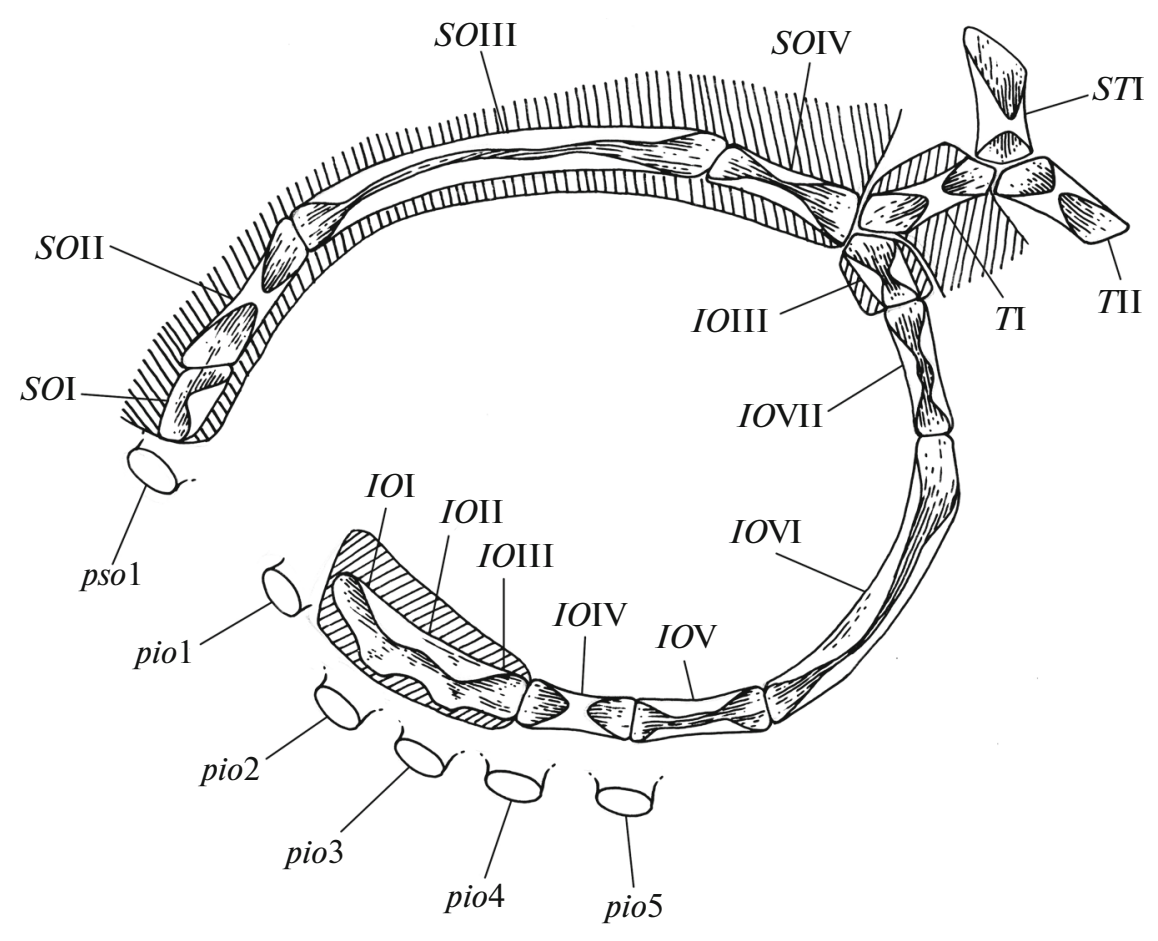

Fig. 3. Scheme of seismosensory canals in the dorsal part of the head in Melanostigma thalassium (paratype, no. $56396 \mathrm{a}-T L 109 \mathrm{~mm}$ ): pso1, SOI-SOIV_first pore and senses of the supraorbital canal (CSO); pio1-pio5, IOI-IOVIII-first five pores and senses of infraorbital canal $(C I O)$; TI, TII-senses of temporal canal $(C T), S T I$-lateral senses of supratemporal commissure $(C S T)$.

(tabulare parietale-STI) on each head side. Medial senses of commissure (tabularia supraoccipitaleSTII) absent. Tabulare parietale and tabulare temporale do not fused with cranial bones.

Lateral line of body with three series of surface neuromasts: predorsal $(P D L L)$, dorsolateral $(D L L)$, and mediolateral $(M L L)$. Neuromasts of whole series quite visible in both holotype and paratype no. 56396 (two to five). These specimens exhibit maximal numbers of distinctly visible neuromasts in $P D L L$ four (five), DLL 13 (12-15), and MLL 32 (26-31).

$\mathrm{Me}$ a surements, in \% $c$ : wc $52.6(46-54.3)$, ch 63.5 (55.6-69.1), $\operatorname{lm} x 35.9$ (27.8-41.9), ao 22.4 (17.8$30.3)$, io 36.5 (33.3-42.1), and $o 30.1$ (31.0-39.7). Measurements of the type specimens in $\% S L$ are present in Table 1.

Coloration. Body not transparent. Color of body, including snout anterior edge and caudal fin, monotonous brown varying from light to dark. Tubes of nostrils, branchial membranes, branchial cavity, oral cavity, and edges of the anus black. Gill arches dark. Gill rakers and gill filaments light brown. High thin layer of tissue of dark-brown color separates gill rakers in external and internal rows. Pectoral fins light brown.

E t y m o log y. Species name formed from ancient

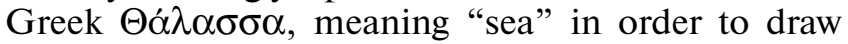
attention to the species relation to the thalssium (nonshelf) biotope in the open ocean.
Distribution and biology. The specimens of the new species were collected in the Southern Hemisphere in early spring (August) with the trawl at 960-1080 $\mathrm{m}$ depths on the southern (according to the classification of Pakhorukov, 1981) site of the Walvis Ridge. The pelagic eelpouts were found on the Valdivia Bank (a northern site of the ridge) by Trunov (1981, P. 53), which were probably assigned to M. thalassium (unfortunately, there is no description in the paper). The attempts to capture of pelagic eelpouts on the Walvis Ridge during the other marine research expeditions failed (Isarev, 1971; Pakhorukov, 1981). It remains unclear whether the new species is present on the Atlantic shelf around South Africa. Such a probability cannot be excluded, since the mesobathybenthic ichthyofauna at the Walvis Ridge includes species typical for the fish fauna of the continental shelf and slope at Southwestern Africa (Trunov, 1968, 1981), despite a certain degree of its endemism. According to the data of Smith (1965), the catches of pelagic eelpouts around Africa are recorded in the regions of Walfish Bay, Port Nolloth, and Cape Town. In addition, the maximum depth of $2561 \mathrm{~m}$ for the pelagic eelpouts capture with the bottom trawl was registered in the last-mentioned region (Anderson, 1986). All the fish collected near the coasts of Africa were identified as M. gelatinosum, while, in our opinion, such an identification became obsolete in the context of the recent concepts of taxonomy. The knowledge of this fish structure, which is based on the 
scarce description (Smith, 1965; Anderson, 1986), requires more profound experience. The southwestern range margin of this new species is also unclear. The opportunity to find the specimen of Melanostigma thalassium on the slopes of the South-Atlantic Ridge cannot be excluded. For the time being, however, there is no reason to extend its range further than the southern extremity of Walvis Ridge. The pelagic eelpouts are not found on the shelf and the mesopelagic zone of the Tristan da Cunha Islands and Gough Island (Andrew et al., 1995), situated southwest of Walvis Ridge. With regard to the pelagic eelpouts captured southwards $\left(41^{\circ}-42^{\circ} \mathrm{S}\right)$ on the Discovery Bank (Trunov, 1985), because of their great similarity to the Meteor Bank in the ichthyofauna, they should more likely be classified into the previously described species of the dark-headed pelagic eelpouts-M. meteori (Balushkin and Orlovskaya, 2019) than be assigned to a new species. The similarities between the two underwater elevations are convincingly evidenced by the following calculations: from 59 species found at Meteor Bank, 52 species (i.e. 88\%) also found on Discovery Bank.

The data on the biology of a new species are not available. There was no type specimens with mature gonads. This can both mean that we are dealing with the juvenile immature specimens (their absolute length is no more than $125 \mathrm{~mm}$ ) or the fish represent another dwarf species of pelagic eelpouts spawning at different times. It can be mentioned in this regard that, among the Kharin's melanostigma $M$. kharini inhabiting the underwater Heracles Ridge (the Pacific-Antarctic Rice) under similar hydrological conditions, the female carrying the mature eggs filling most of body cavity were found in the Southern Hemisphere in early summer (December) (Balushkin and Moganova, 2018). A very unusual way of spawning in the mesobenthic zone at approximately $350 \mathrm{~m}$ depth in the small holes created by the fish in the gravel is recorded in the North atlantic melanostigma M. atlanticum (Silverberg et al., 1987). Such a choice of spawning substrate allowed us to assign this species to the specific ecological group of infernophylic fish (Latin "infernus" means existing in the subterranian kingdom, underground) (Balushkin and Moganova, 2017).

If infernofillia is typical for the species of Melanostigma thalassium, there is silt at the fish's disposal covering the bottom of the Walvis Ridge; the silt aggregates are mostly agglutinating foraminifora, forming deeper sediment accumulation on the tops of the ridge (Pakhorukov, 1981).

Comparative comments. An important apomorphic character of the new species is the supratemporal commissure interruption, which is also typical for three species Melanostigma: M. atlanticum, M. orientale, and M.japonicum in the Northern Hemisphere. However, it is not known in any other species inhabiting the waters in the Southern Hemisphere. In addition, all the mentioned species of the Northern Hemisphere are well distinct from M. thallasium in a light transparent body (their snout and caudal edges are only dark) and the large number of vertebrae (vert. 93-99 in M. atlanticum, 93-100 in M. orientale, 100 in M. japonicum vs. 90-92 in M. thallasium). Such a large number of vertebrae may be explained by the fact that the species formation took place during the glacial periods in the Pliocene and Pleistocene Epochs, resulting in the reduction in the water temperature in the north of the Atlantic and Pacific Oceans.

The fourth species of Melanostigma in the Northern Hemisphere is the Black melanostigma M. pammelas, commonly known from the coastal region of the Pacific Ocean at North America. It is quite different from the new species by the presence of a coronal commissure that connects supraorbital canals of both sides of the head, the complete absence of supratemporal commissure as well as lack of postcleithrum (Anderson, 1994). According to the previously proposed evolutionary scenario (Balushkin, 2019), the pelagic eelpouts in the Northern Hemisphere are the descendants of the ancestral form that arose via paedomorphosis. All of them are dwarf species, $T L \leq 160 \mathrm{~mm}$ (usually $<140 \mathrm{~mm}$ ). Despite the reconstruction of the individual development via paedomorphosis, the response of pelagic eelpouts to the severe climate change became its adaptation to a greater depth, where the change in the temperature regime during a cold snap occurred less abruptly. Genetic exchange between the Pacific and Atlantic populations of pelagic eelpouts was terminated after the closure of the Panama Isthmus in the Pliocene. Later, the interactions between the oceans existed through the Bering Strait, which repeatedly opened in the Pleistocene (Petrov, 1976). However, the pelagic eelpouts could scarcely use this way, because of the strait shallowness. If the North-Atlantic pelagic eelpouts M. atlanticum tended to migrate through the northern and northwestern waters up to the shelf of the Western Sahara, the Thalassian pelagic eelpouts $M$. thalassium tended to distribute southwards along the Mid-Atlantic Ridge, reaching the latitude of the Walvis Ridge. Among species of Melanostigma in the Southern Hemisphere, the pelagic eelpouts found in the waters around New Zealand and described by Møller and Anderson (2015) under the name $M$. inexpectatum (non Parin, 1977), which is incorrect in our opinion, may appear to be a form rather similar to $M$. thallasium. The New Zealand fish are likely to be close to the new species for the similar numbers of rays in the dorsal and anal fins, the lack of a temporal pore, and a monotonously dark body color.

However, the more definite conclusions of their similarities can be drawn after studying the topography of the head's seismosensory canal system.

The key provided below would help in identifying new species in the Atlantic Ocean. 


\section{KEY OF MELANOSTIGMA SPECIES IN THE ATLANTIC OCEAN}

1 (4) Temporal canal pore present. Supratemporal commissure complete.

2 (3) $88-90$ vertebrae, including $21-22$ abdominal vertebrae and 67-69 caudal vertebrae. $83-86$ rays in $D$. Ventral series of surface neuromast on body lateral line present. Head top monotonous dark (Meteor Bank, Southeast Atlantic)

\section{M. meteori Balushkin et Orlovskaya}

3 (2) 82-85 vertebrae, including 19-21 abdominal vertebrae and 62-64 caudal vertebrae. $80-84$ rays in $D$. Ventral series of surface neuromast on body lateral line absent. Head top light color with frequent small spots (Atlantic and Pacific coasts of South America and at Strait of Magellan) ...... M. gelatinosum Günther

4 (1) Temporal pore absent. Supratemporal commissure interrupted in middle.

5 (6) 90-92 vertebrae, including 20-21 abdominal vertebrae and $70-71$ caudal vertebrae. 8-10 rays in pectoral fin. Body lateral line with three series of neuromasts (predorsal, dorsal-lateral, and mediolateral). Body not transparent. Color of laterals light to darkbrown (Walvis Ridge, Southeast Atlantic)

M. thalassium Orlovskaya et Balushkin, sp.n.

6 (5) 93-99 vertebrae, including $18-20$ abdominal vertebrae and 73-78 caudal vertebrae. 6-9 rays in pectoral fin. Body lateral line absent. Body transparent. Laterals light with some silver-like patina and, sometimes, with pink color tint in anterior body side (North Atlantic, in west from Newfoundland southwards to Hatteras Island, in east from Scotland to Western Sahara and Western Mediterranean Sea) ........ M. atlanticum Koefoed

\section{ACKNOWLEDGMENTS}

We are grateful to I.A. Trunov, a collector (All-Russia Research Institute of Fishery and Oceanography, Atlantic Branch), for sampling and transporting the eelpout fish collected in the Southeast Atlantic and Dr. P. Møller (P.R. Møller, University of Copenhagen) for providing the specimen of Melanostigma atlanticum from the Denmark Straight. We are also grateful to S.A. Evseenko (Shirshov Institute of Oceanology, Russian Academy of Sciences) for his suggestions, which have been helpful in improving the manuscript.

\section{FUNDING}

The work was supported by the State research theme no. AAAA-A19-119020790033-9.

\section{OPEN ACCESS}

This article is distributed under the terms of the Creative Commons Attribution 4. International license (http://creativecommons.org/licenses/by/4.0/), which permits unre- stricted use, distribution, and reproduction in any medium, provided you give appropriate credit to the original author(s) and the source, provide a link to the Creative Commons license, and indicate if changes were made.

\section{COMPLIANCE WITH ETHICAL STANDARDS}

Conflict of interests. The authors declare that they have no conflict of interests.

Statement of the welfare of animals. All applicable international, national, and/or institutional guidelines for the care and use of animals were followed.

\section{REFERENCES}

Anderson, M.E., Family no. 94: Zoarcidae, in Smiths' Sea Fishes, Smith, M.M. and Heemstra, P.C., Eds., Grahamstown: Macmillan S. Africa Publ., 1986, p. 343.

Anderson, M.E., Studies on the Zoarcidae (Teleostei: Perciformes) of the southern hemisphere. I. The Antarctic and subantarctis regions, in Biology of the Antarctic Seas XIX, New York: Wiley, 1988, vol. 47, pp. 59-113.

Anderson, M.E., Zoarcidae, in Fishes of the Southern Ocean, Gon, O. and Heemstra, P.C., Eds., Grahamstown: J.L.B. Smith Inst. Ichthyol., 1990, pp. 257-276.

Anderson, M.E., Systematics and osteology of the Zoarcidae (Teleostei: Perciformes), Ichthyol. Bull. J.L.B. Smith Inst. Ichthyol., 1994, no. 60, pp. 1-120.

Andrew, T.G., Hecht, T., Heemstra, P.C., and Lutjeharms, J.R.E., Fishes of the Tristan da Cunha Group and Gough Island, South Atlantic Ocean, Ichthyol. Bull. J.L.B. Smith Inst. Ichthyol., 1995, no. 63, pp. 1-41.

Balushkin, A.V., Description of a new species of pelagic eelpouts Melanostigma japonicum sp. nova (Zoarcidae) from the Pacific coast of South Japan with a key for the species of the genus Melanostigma from the Pacific Ocean and the adjacent waters of the Indian and Southern Oceans, J. Ichthyol., 2019, vol. 59, no. 3, pp. 283-288.

https://doi.org/10.1134/S0032945219030019

Balushkin, A.V. and Moganova, M.V., New species of pelagic eelpouts of the genus Melanostigma (Zoarcidae) from Western Antarctica, J. Ichthyol., 2017, vol. 57, no. 2, pp. $171-176$.

https://doi.org/10.1134/S0032945217020011

Balushkin, A.V. and Moganova, M.V., Melanostigma khari$n i$ sp. nov. (Zoarcidae), a new species of pelagic eelpout from the Ridge of Hercules (Pacific-Antarctic Rise), J. Ichthyol., 2018, vol. 58, no. 2, pp. 139-147.

https://doi.org/10.1134/S0032945218020029

Balushkin, A.V. and Orlovskaya, M.V., Melanostigma meteori sp. n. (Zoarcidae): a new pelagic eelpout species from the Meteor Bank (Southeastern Atlantic), with remarks on the polymerization of the lateral line in the family, J. Ichthyol., 2019, vol. 59, no. 2, pp. 135-143.

https://doi.org/10.1134/S0032945219020036

Balushkin, A.V., Sheiko, B.A., and Fedorov, V.V., Catalog of the archival collection of the Zoological Institute, Russian Academy of Sciences: Class Osteichthyes (bony fishes), order Perciformes, family Zoarcidae, J. Ichthyol., 2011, vol. 51, pp. 950-1034. 
Balushkin, A.V., Sheiko, B.A., and Prirodina, V.P., Catalog of the archival collection of the Zoological Institute, Russian Academy of Sciences. Class Osteichthyes. Order Perciformes. Suborder Zoarcoidei. Families: Bathymasteridae, Zoarcidae, Cryptacanthodidae, Ptilichthyidae, and Zaproridae. Suborder Icosteoidei. Family Icosteidae, in Issledovanie fauny morei (Exploration of the Fauna of the Seas), St. Petersburg: Zool. Inst., Ross. Akad. Nauk, 2012, vol. 71 (79).

Isarev, A.T., The results of research works on the Valdivia Bank, Tr. Atl. Nauchno-Issled. Inst. Rybn. Khoz. Okeanogr., 1971, no. 41, pp. 78-81.

McAllister, D.E. and Ress, E.J.S., A revision of the eelpout genus Melanostigma with a new genus and with comments on Maynea, Bull. Nat. Mus. Can., 1964, vol. 199, pp. 85110.

McAllister, D.E., Anderson, M.E., Hunter, J.G., Deepwater eelpouts, Zoarcidae, from Arctic Canada and Alaska, Can. J. Fish. Aquat. Sci., 1981, vol. 38, pp. 821-839.

Møller, P.R. and Anderson, M.E., 204 Family Zoarcidae, in The Fishes of New Zealand, Vol. 4: Systematic Accounts, Roberts, C.D., et al., Eds. Wellington: Te Papa Press, 2015, pp. 1424-1432.

Nakamura, I., Zoarcidae, in Important Fishes Trawled off Patagonia, Nakamura, I., , Eds., Tokyo: Jpn. Mar. Fish. Resour. Res. Center, 1986, pp. 238-243.

Pakhorukov, N.P., Deep-sea bottom fishes of the Whale Ridge and adjacent areas, in Ryby otkrytogo okeana (Fishes of the Open Ocean), Moscow: Inst. Okeanol. im. P.P. Shirshova, 1981, pp. 19-35.

Parin, N.V., New species of genus Melanostigma (Zoarcidae, Osteichthyes)-Melanostigma inexpectatum from the western equatorial part of Pacific Ocean, Tr. Inst. Okeanol. im. P.P. Shirshova, Akad. Nauk SSSR, 1977, vol. 107, pp. 63-68.

Parin, N.V., Melanostigma (Bandichthys) vitiazi (Melanostigmatidae, Osteichthyes) is a new deepwater fish from the Banda Sea, Vopr. Ikhtiol., 1979, vol. 19, no. 1 (114), pp. 167-170.

Petrov, O.M., Geological history of the Bering Strait in Late Cainozoe, in Beringiya v kainozoe (Beringia in Cainozoe), Vladivostok: Dal'nevost. Nauchn. Tsentr, Akad. Nauk SSSR, 1976, pp. 28-33.

Silverberg, N., Edenborn, H.M., Ouellet, G., and Béland, P., Direct evidence of a mesopelagic fish, Melanostigma atlanticum (Zoarcidae) spawning within bottom sediments, Environ. Biol. Fish., 1987, vol. 20, no. 3, pp. 195-202.

Smith, J.L.B., The Sea Fishes of Southern Africa, Cape Town: Central News Agency, 1965.

Tominaga, Y., Melanostigma orientale, a new species of zoarcid fish from Sagami Bay and Suruga Bay, Japan, Jpn. J. Ichthyol., 1971, vol. 18, no. 4, pp. 151-156.

Trunov, I.A., Preliminary data on the composition and distribution of some fishes from the southeast Atlantic, Vopr. Ikhtiol., 1968, vol. 8, no. 5 (52), pp. 952-954.

Trunov, I.A., Metodicheskie ukazaniya po opredeleniyu ikhtiofauny batiali i podvodnykh vozvyshennostei yugo-vostochnoi Atlantiki (Methodological Recommendations for Identification of Ichthyofauna of Bathyal and Submerged Rises of the Southeastern Atlantic), Kaliningrad: Atl. NauchnoIssled. Inst. Rybn. Khoz. Okeanogr., 1979.

Trunov, I.A., Ichthyofauna of submerged Valdivia Bank (Southeastern Atlantic), Byull. Mosk. O-va. Ispyt. Prir., Otd. Biol., 1981, vol. 86, no. 2, pp. 5-64.

Trunov, I.A., Ichthyofauna in the area of oceanic rises of the eastern part of the Sub-Antarctic and Antarctic, in Kompleksnoe izuchenie bioproduktivnosti vod Yuzhnogo okeana (Comprehensive Study of Biological Productivity of Waters of the Southern Ocean), Moscow: Minrybkhoz, 1985, vol. 2, pp. 287-315.

Translated by $O$. Zhiryakova 